\title{
Surgical Treatment of Multiple Intracranial Aneurysms
}

\section{Multipl Intrakraniyal Anevrizmalarn Cerrabi Tedavisi}

\author{
Suocheng GUO, Yazhou XING \\ Henan Province People's Hospital, Department of Neurosurgery, Zhengzhou, China
}

Corresponding Author: Yazhou XING / E-mail: scyzcn@126.com

\begin{abstract}
AIM: To discuss the surgical methods for multiple intracranial aneurysms.

MATERIAL and METHODS: 23 patients were divided into three groups according to the location of the aneurysms: aneurysms located in one side or in the midline of the Willis ring; aneurysms located on both sides of the Willis ring with unruptured aneurysms located ahead of the middle cerebral artery bifurcation; and MIAs located on both sides with unruptured aneurysms located in the middle cerebral artery bifurcation or distal bifurcation. The preoperative operation strategy was made according to different groups.

RESULTS: All patients in the first group underwent a one-stage operation for occlusion of all aneurysms. In the second group, eight patients underwent a one-stage operation for occlusion of all arterial aneurysms while the other three patients underwent a one-stage operation for occlusion of the ipsilateral aneurysms, followed by a two-stage operation for occlusion of the contralateral arterial aneurysms. In the third group, all patients underwent a two-stage operation for occlusion of all aneurysms. Good recovery, moderate disability, and severe disability were observed in 19, 2, and 2 cases, respectively.
\end{abstract}

CONCLUSION: One-stage or two-stage surgery was determined based on the distribution of multiple aneurysms and the intraoperative situation to achieve ideal treatment effects.

KEYWORDS: Multiple intracranial aneurysms, Surgery, Therapeutic effect

öz

AMAÇ: Multipl intrakraniyal anevrizmalar için cerrahi yöntemleri tartışmak.

YÖNTEM ve GEREÇLER: Anevrizmaların konumuna göre 23 hasta üç gruba ayrılmıştır: Willis poligonunun bir tarafında veya ortada bulunan anevrizmalar; Willis halkasının her iki tarafında bulunan ve orta serebral arter bifurkasyonunun ilerisinde rüptüre olmamış anevrizmaları bulunan hastalar ve her iki tarafta bulunan ve orta serebral arter bifurkasyonunda veya distal bifurkasyonda rüptüre olmamış anevrizmaları bulunan hastalar. Preoperatif ameliyat stratejisi farklı gruplara göre düzenlenmiştir.

BULGULAR: Birinci gruptaki tüm hastalara tüm anevrizmaların oklüzyonu için tek evreli bir ameliyat yapılmıştır. İkinci grupta sekiz hastada tüm arteriyel anevrizmaların oklüzyonu için tek evreli bir ameliyat yapılırken diğer üç hastada ipsilateral anevrizmaların oklüzyonu için tek evreli bir ameliyat yapılmış ve sonrasında kontralateral arteriyel anevrizmaların oklüzyonu için iki evreli ameliyat yapılmıştır. Üçüncü grupta tüm hastalara tüm anevrizmaların oklüzyonu için iki evreli bir ameliyat yapılmıştır. İyi iyileşme, orta derecede maluliyet ve şiddetli maluliyet sırasıyla 19, 2 ve 2 olguda görülmüştür.

SONUÇ: İdeal tedavi etkinliğine ulaşabilmek için bir evreli veya iki evreli cerrahi, multipl anevrizmaların yerleşimine ve intraoperatif duruma göre belirlenmiştir.

ANAHTAR SÖZCÜKLER: Multipl intrakraniyal anevrizmalar, Cerrahi, Terapötik etki

\section{INTRODUCTION}

Multiple intracranial aneurysms (MIAs) are two or more intracranial aneurysms that exist in the cranium. To date, the genesis and pathogenesis of MIA are not clearly elucidated. MIA occurs in more women, especially postmenopausal women, than in men. This phenomenon may be related to the loss of estrogen protection. MIA patients are associated with IgE syndrome (20). Moreover, patients with atrial myxoma and cerebral vascular malformations could also be suffering from MIA $(7,11)$. MIA coexists with various vascular malformations (12). Hypertension and bad habits, such as drinking and, smoking, can induce multiple aneurysms. MIA detection has gradually become widespread because of the popularity of cerebral angiography. Takeuchi reported that MIA accounts for about a third of the patients with subarachnoid hemorrhage (6). The Beijing Tiantan Hospital reported that MIA cases account for $8.1 \%(123 / 1511)$ of all treated cases of aneurysms in the same period (19). A combination of surgical operation and endovascular treatment, as well as simple surgical treatment, has been recommended for MIA treatment $(2,11)$. The surgical operation of MIA is complex. The common operating principle is to initially determine the 
correct offending aneurysm among the multiple aneurysms for occlusion. The decision regarding the type of surgery to be used (either one-stage or multiple-stage surgery) as an operation strategy for multiple aneurysms and the location of bilateral multiple aneurysms (either along the bilateral approach or the unilateral approach) are still not clearly elucidated. This study includes surgeries on 23 cases of multiple aneurysms. The clinical characteristics, surgical experiences, and treatment outcomes of these multiple aneurysm cases were reported.

\section{SUBJECTS and METHODS}

\section{General Data}

We retrospectively analyzed 23 patients with multiple aneurysms who underwent surgery from October 2003 to October 2012. Among the 23 patients, 9 were males and 14 were females, with ages ranging from 36 to 71 years (average age, 52 years old). 23 patients were divided into three groups according to the location of the aneurysms: 1) MIAs located in one side or midline. The distribution of MIAs were not exceeding contralateral A1-A2 junction or the top of the basilar artery; 2) MIAs located on both sides, and unruptued aneurysms located between contralateral A1-A2 junction and contralateral MCA bifurcation (not including the bifurcation). The data of patients are shown in Table I. Eight of these patients had history of hypertension. This study was conducted in accordance with the declaration of Helsinki. This study was conducted with approval from the Ethics Committee of Henan province people's hospital. Written informed consent was obtained from all participants.

All 23 patients had history of subarachnoid hemorrhage. Twenty-two patients had one occurrence of hemorrhage and one patient had two occurrences of hemorrhage. Sudden severe headache, loss of consciousness, and nausea and vomiting were experienced in 14, 9, and 17 patients, respectively. Three patients experienced oculomotor paralysis and one patient had unilateral decreased muscle strength (level IV). According to the Hunt-Hess clinical classification,
$3,11,6,2$, and 1 patients belonged to levels $1,2,3,4$ and 5, respectively.

\section{Iconography}

Thirteen patients underwent preoperative cerebrovascular DSA examination, seven patients underwent CTA examination, and three patients underwent both examinations. Two aneurysms were preoperatively detected in 16 cases, three aneurysms in six cases, and four aneurysms in one case. The 23 patients were divided into three groups according to the distribution of multiple aneurysms (Figure 1). The first group comprised seven cases. All of their aneurysms were located in one side or the midline. The distribution of the MIAs did not exceed contralateral A1-A2 junction or the top of the basilar artery. A total of 11 cases comprised the second group. Their aneurysms were located on both sides, and unruptued aneurysms located between contralateral A1-A2 junction and contralateral MCA bifurcation (not including the bifurcation). The third group was composed of five cases. MIAs of the third group were located on both sides with unruptured aneurysms located on the contralateral middle cerebral artery bifurcation and distal bifurcation.

\section{Surgical Method}

A total of 17,5 , and 1 patients underwent surgery after bleeding for 0-3 days, 3-21 days, and 21 days, respectively. The offending aneurysm was identified among multiple aneurysms. The patients underwent a one-stage surgery for craniotomies on the side of the offending aneurysms along the unilateral pterional approach. Moreover, these patients also underwent occlusion of ruptured aneurysms, and unruptured aneurysms were exposed in a similar approach. The aneurysms that failed to occlude in the one-stage surgery were clipped in a two-stage surgery along the contralateral pterional approach instead of a one-stage surgery for bilateral craniotomies after 1-2 month recovery. In the first group, all of the aneurysms were located in one side or the midline of the Willis ring along the unilateral pterional approach to expose all multiple aneurysms. These patients were expected to

Table I: The Distribution, Operation Strategy and Results of MIAs

\begin{tabular}{|l|l|l|l}
\hline $\begin{array}{l}\text { Ruptured aneurysm } \\
\text { location }\end{array}$ & $\begin{array}{l}\text { First group (7 cases) } \\
\text { PCoA 3, AcoA 1 }\end{array}$ & $\begin{array}{l}\text { Second group (11 cases) } \\
\text { ACA-A1 1, ophthalmic artery 1, } \\
\text { MCA-M2 1, MCA-bifurcation 3, } \\
\text { PCoA 5 }\end{array}$ & $\begin{array}{l}\text { MCA-bifurcation 2, PCoA 2, } \\
\text { ophthalmic artery 1 }\end{array}$ \\
$\begin{array}{l}\text { Unruptured } \\
\text { aneurysm location }\end{array}$ & $\begin{array}{l}\text { ipsilateral: PCoA 2, AcoA 3, ACA } \\
\text {-A1 1, MCA-M2 1, MCA-M1 1, } \\
\text { ophthalmic artery 1. }\end{array}$ & $\begin{array}{l}\text { Ipsilateral: AcoA 1, PCoA 3, } \\
\text { MCA-bifurcation 2 contralateral: } \\
\text { MCA-M1 2, PCoA 6, ophthalmic } \\
\text { artery 2, ACA -A1 1 }\end{array}$ & $\begin{array}{l}\text { Contralateral: MCA-M2 1, MCA- } \\
\text { bifurcation 4 }\end{array}$ \\
\hline $\begin{array}{l}\text { Operation strategy } \\
\text { Result }\end{array}$ & $\begin{array}{l}\text { One-stage operation 7. } \\
\text { One-stage operation 8, two- } \\
\text { stage operation 3. } \\
\text { Good recovery 5, moderate } \\
\text { disability 1, severe disability 1. }\end{array}$ & $\begin{array}{l}\text { Good recovery 10, severe } \\
\text { disability 1 }\end{array}$ & $\begin{array}{l}\text { Two-stage operation 5 } \\
\text { Good recovery 4, moderate } \\
\text { disability 1 }\end{array}$ \\
\hline
\end{tabular}




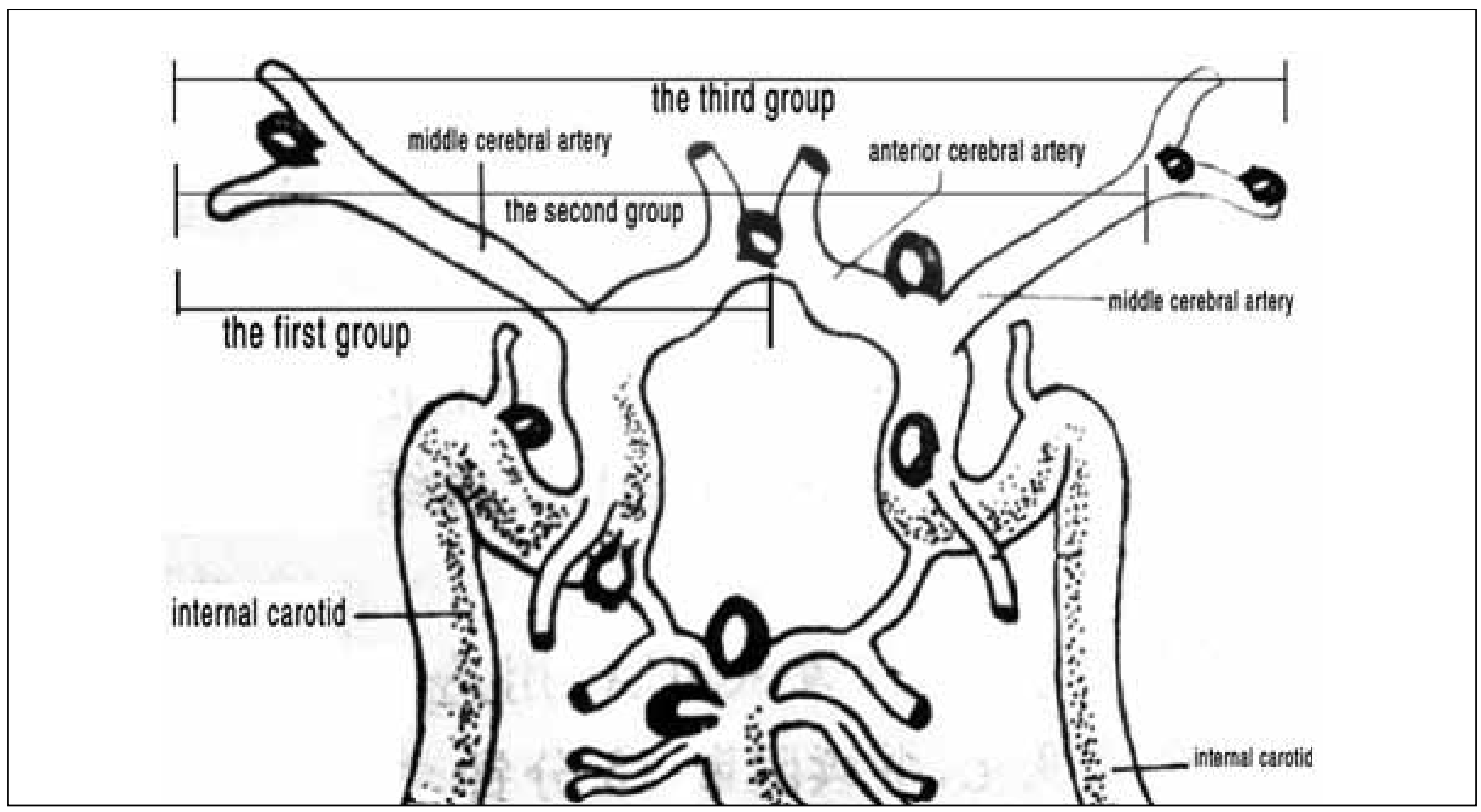

Figure 1: The distribution of MIAs and the groups.

undergo a one-stage surgery for occlusion of all aneurysms. In the second group, the aneurysms were located in both sides with unruptured aneurysms located between contralateral A1-A2 junction and contralateral MCA bifurcation. Given the existence of microneurosurgery technology, all of the arterial aneurysms could be exposed along the unilateral pterional approach. However, the decision on the type of surgery to be used, i.e., one-stage surgery or multiple-stage surgery, is also based on the cerebral edema and intraoperative exposure because multiple aneurysms of this group are bilaterally distributed. In the third group, aneurysms were located on both sides, and unruptured aneurysms were located on the middle cerebral artery bifurcation or distal bifurcation. Given that distal aneurysms along the unilateral pterional approach were difficult to expose in a one-stage surgery, these patients underwent a multiple-stage surgery. Patients underwent conventional craniotomy along the pterional approach. The entire segment of the lateral fissure underwent intraoperative dissection. The lateral fissure pool, the internal carotid artery pool, and the optic chiasm pool were opened to release the cerebrospinal fluid and allow the brain tissues to fully rebound. The perivascular arachnoid was cut according to the following order: ipsilateral middle cerebral artery, internal carotid artery, anterior cerebral artery at the A1 segment, and anterior communicating artery complex. The position of the brain spatula was regulated, and the arachnoid was cut and separated from the anterior communicating artery to the contralateral anterior cerebral artery at the A1 segment to expose the contralateral carotid artery and contralateral middle cerebral artery at the M1 segment. The corresponding aneurysms on the blood vessels were successively occluded according to the aforementioned order. If two aneurysms existed in short distances, the ruptured aneurysms were initially occluded, followed by the unruptured aneurysms. A drainage tube was postoperatively inserted in the lateral fissure for drainage of cerebrospinal fluid for 2-3 days.

\section{RESULTS}

\section{General Data}

Thirty-one craniotomies were completed and 54 aneurysms were occluded. In the first group, all of the seven patients underwent occlusion of all aneurysms along the unilateral pterional approach. In the second group, among the 11 patients, eight underwent one-stage surgery for occlusion of all aneurysms along the unilateral approach. The other three patients underwent one-stage surgery for occlusion of ipsilateral aneurysms and two-stage surgery for occlusion of contralateral aneurysms. In the third group, all of the five patients underwent two surgeries for occlusion of aneurysms along the bilateral approach. Among the 23 patients, 15 underwent one-stage surgery for occlusion of all aneurysms along the unilateral pterional approach and 8 underwent two surgeries for occlusion of all aneurysms along the bilateral approach.

\section{Postoperative GOS Score}

No deaths occurred in this study. According to the GOS score, 19 cases had good recovery, 2 cases had moderate disabilities, and 2 cases had severe disabilities. A total of four patients had postoperative subcutaneous effusion, which disappeared after lumbar drainage for 3-5 days. The postoperative review 
of CT showed two cases of cerebral infarction. Seventeen patients were followed up for one month to six years, and no further bleeding was noted. Fourteen patients underwent postoperative 64-row CTA reviews (21), which indicated that the aneurysms had disappeared.

\section{Typical Cases}

\section{Case 1}

Case 1 was a male patient aged 45 years without a history of hypertension. He suffered from sudden headache and nausea for half an hour prior to hospital admission. The patient was conscious upon admission. According to the Hunt-Hess clinical classification, this case belonged to Level 1. Cranial CT scan showed subarachnoid hemorrhage, mainly in the left (Figure 2A). 3D-CTA indicated left middle cerebral artery bifurcation aneurysm as the offending aneurysm and right middle cerebral artery aneurysm at the $M 1$ segment (Figure 2B). This patient recovered normal life and work after one-stage surgery for occlusion of bilateral middle cerebral artery aneurysms along the left unilateral pterional approach. 3D-CTA review showed that the bilateral aneurysm had been occluded (Figure 2C,D).

\section{Case 2}

Case 2 was a male patient aged 48 years with a history of drinking and smoking for more than 20 years but without a history of hypertension. This patient suffered subarachnoid hemorrhage six years before admission to the hospital. DSA showed left internal carotid artery-posterior communicating
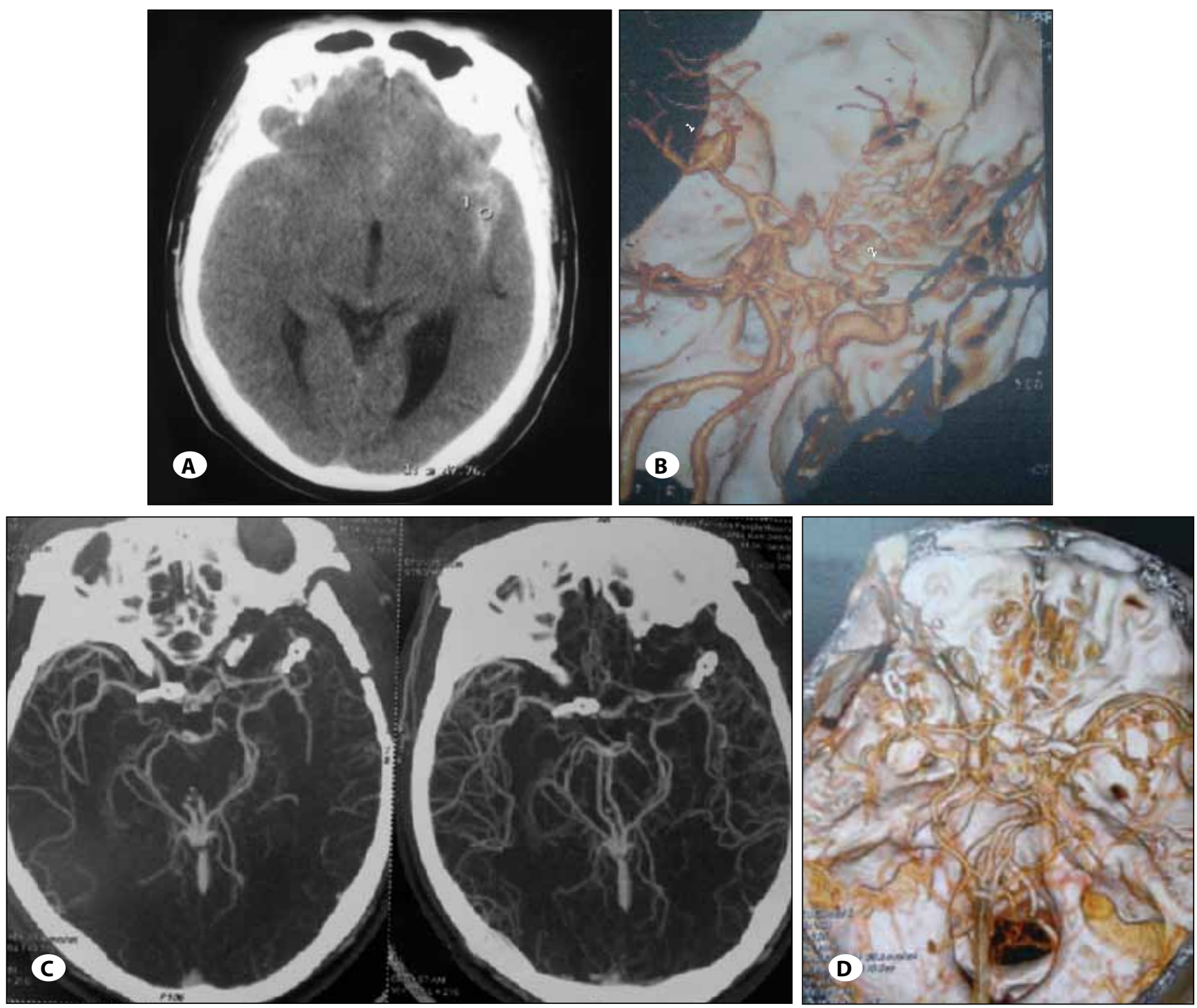

Figure 2: A) Cranial CT scan showed subarachnoid hemorrhage, mainly in the left. B) 3D-CTA showing the left middle cerebral artery bifurcation aneurysm (1) which is the offending aneurysm and the right middle cerebral artery aneurysm at the M1 segment (2). C) Postoperative CTA review showing the skull incision and aneurysm clip after the occlusion of bilateral middle cerebral artery aneurysms along the left pterional approach. D) Postoperative 3D-CTA review showing aneurysm occlusion. 
artery aneurysms, without abnormality in the rest of the cerebral vessels. He underwent endovascular treatment of aneurysms at the Interventional Department. Six years later, this patient again suffered sudden coma and respiratory failure. This case belonged to Level 5 according to the Hunt-Hess clinical classification. CT examination showed subarachnoid hemorrhage and bilateral intraventricular hematomas. Thereafter, this patient underwent bilateral decompressive craniectomy and external ventricular drainage. DSA cerebral angiography showed three new aneurysms, including right middle cerebral artery aneurysms, right internal carotid artery-posterior communicating artery aneurysms, and anterior communicating artery aneurysms. The anterior communicating artery aneurysms were the offending aneurysms in this patient. After 23 days, the breathing of the patient became stable. He underwent occlusion of multiple aneurysms along the unilateral approach, and bleeding was not observed after surgery. However, this patient had severe disability and was bedridden postoperatively.

\section{DISCUSSION}

Based on previous studies, MIA mostly occurs in the intracalvarium. Thus, proper determination of the offending aneurysm and initially undergoing occlusion are necessary. Different indices have been established by imaging observation to distinguish ruptured aneurysms from unruptured aneurysms. Baumann (1) observed that larger aneurysms and anterior communicating aneurysms often rupture. The size ratio (SR) value of the ruptured aneurysms is significantly larger than unruptured aneurysms. This result is based on the ratio of aneurysms and aneurysmal arteries by Rahman (16). The increased bottleneck factor and the height-width ratio are considered inherent characteristics of the ruptured aneurysms in the control of ruptured and unruptured aneurysms by Hoh (8). In the present group of cases, the offending aneurysm was determined mainly based on the (1) bleeding site. Preoperative CT showed that subarachnoid hemorrhage occurred more frequently beside the ruptured aneurysms. Interhemispheric hemorrhage or bilateral intraventricular hemorrhage occurred more in the anterior communicating artery aneurysm; the adjacent aneurysm of intracerebral hematoma was the offending aneurysm. Aneurysm was also identified according to its (2) morphology and near vascular response. In the DSA or CTA image, the spasm coarctation of aneurysmal arteries near to the ruptured aneurysm was obvious. The ruptured aneurysm had a coarse edge and irregular filling. Based on observation, determining the offending aneurysm using the general method is difficult in some cases. In this study, the aneurysms were occluded according to the order of exposure. In some cases,unruptured aneurysm initially underwent occlusion. For example, if the anterior communicating artery aneurysm coexisted with the posterior communicating artery aneurysm, and the anterior communicating artery aneurysm hemorrhage. The unruptured posterior communicating artery aneurysm initially underwent occlusion and then the ruptured anterior communicating artery aneurysm was clipped according to the exposed order. Therefore, the intraoperative rupture of non-ruptured aneurysms caused by surgical retraction was avoided. Determining which side bleeds, either anterior or posterior circulation hemorrhage, is important to clip the ruptured aneurysm successfully.

This study divided the groups according to the position of MIA. In the first group, multiple aneurysms were located on one side or in the midline. The occlusions of all aneurysms were completed along the unilateral pterional approach. In the second and third groups, multiple aneurysms were located on both sides. Both groups were separated by the boundary of contralateral middle cerebral artery bifurcation. Although a number of reports are available on occlusion of bilateral aneurysms in the middle cerebral artery bifurcation along the unilateral approach $(10,13)$, according to Oshiro's study (14), contralateral middle cerebral artery bifurcation is difficult to observe along the unilateral pterional approach when the contralateral M1 segment is $>14 \mathrm{~mm}$. Considering the surgical safety, aneurysms in the contralateral middle cerebral artery bifurcation were included in the third group. The contralateral aneurysms in the third group were located in the middle cerebral artery bifurcation and distal bifurcation. Exposing and occluding the contralateral aneurysms along the unilateral pterional approach are difficult; thus, bilateral craniotomy is necessary. Among the 11 patients in the second group, eight underwent one-stage surgery for occlusion of all aneurysms along the unilateral pterional approach and three underwent two-stage surgery. Controversies still exist on the strategies of bilateral MIA. Patients undergo onestage surgery (5) or multiple-stage surgery (17) for bilateral craniotomy, but recently, more bilateral multiple aneurysms have been occluded along the unilateral approach in onestage surgery $(3,9,17,18)$. Preoperative evaluation of patients is helpful in deciding the type of surgery to be used (i.e., one-stage surgery or multiple-stage surgery). One-stage unilateral craniotomy has obvious advantages compared with one-stage bilateral craniotomy. These advantages include reduced surgical trauma and short operation time. One-stage unilateral craniotomy allows wider dissection and separation of arachnoid, which are beneficial in removing subarachnoid hematoma, draining bloody cerebrospinal fluid, and reducing vascular spasm (4). Given that the contralateral aneurysm is expected to be intraoperatively exposed, a comprehensive consideration should be combined, such as aneurysmal complexity and degree of cerebral edema. In this study, the patients underwent contralateral operation along the unilateral pterional approach, which was deeply located in the narrow field of vision, with higher requirements of neurosurgical instruments and operating technologies. The entire segment of the lateral fissure underwent full intraoperative dissection. The cerebrospinal fluid was fully released to fully rebound the brain tissue. The blood vessels were gradually exposed according to the following order: ipsilateral middle cerebral artery, ipsilateral internal carotid artery, ipsilateral anterior cerebral arteries at the A1 segment, anterior communicating artery, contralateral anterior 
cerebral artery at the A1 segment, contralateral internal carotid artery, and contralateral middle cerebral artery. The aneurysms were occluded according to the aforementioned order. The drainage tube was inserted in the lateral fissure for drainage of hemorrhagic cerebrospinal fluid. This tube reduced intracranial pressure and cerebrovascular stimulus of subarachnoid hemorrhage. Three cases of aneurysms were not occluded along the unilateral approach in the second group because of the following reasons: (1) Along the unilateral approach, the outside bottom of the contralateral internal carotid artery was poorly exposed because of its location. This phenomenon prevented the corresponding aneurysms to be fully exposed. (2) The serious cerebral edema caused an unideal rebound of brain tissue, which could not expose the opposite side despite utilization of measures such as dehydration and release of cerebrospinal fluid.

Among these cases, one case (typical Case, Patient 12) had rare cerebral de novo aneurysm. The patient again suffered multiple aneurysms, bleeding, and postoperative severe disability after being treated for six years. Therefore, followup imaging was recommended to patients who still had aneurysms 10 years after the first treatment (15).

\section{REFERENCES}

1. Baumann F, Khan N, Yonekawa Y: Patient and aneurysm characteristics in multiple intracranial aneurysms. Acta Neurochir Suppl 103: 19-28, 2008

2. Chung J, Shin YS: Multiple intracranial aneurysms treated by multiple treatment modalities. Neurosurgery 69: E10301032, 2011

3. Clatterbuck RE, Tamargo RJ: Contralateral approaches to multiple cerebral aneurysms. Neurosurgery 57(1 Suppl): 160163, 2005

4. de Aguiar PH, Barros I, Paiva BL, Simm RF: Removal of clots in subarachnoid space could reduce the vasospasm after subarachnoid hemorrhage. Acta Neurochir Suppl 115: 91-93, 2013

5. Dunn GP, Nahed BV, Walcott BP, Jung H, Tierney TS, Ogilvy CS: Dual ipsilateral craniotomies through a single incision for the surgical management of multiple intracranial aneurysms. World Neurosurg 77: 502-506, 2012

6. Ellamushi HE, Grieve JP, Jäger HR, Kitchen ND: Risk factors for the formation of multiple intracranial aneurysms. J Neurosurg 4: 728-732, 2001

7. Gorge KJ, Rennie A, Saxena A: Multiple cerebral aneurysms secondary to cardiac myxoma. Br J Neurosurg 26: 409-411, 2012

8. Hoh $\mathrm{BL}$, Sistrom $\mathrm{CL}$, Firment $\mathrm{CS}$, Fautheree $\mathrm{GL}$, Velat $\mathrm{GJ}$, Whiting JH, Reavey-Cantwell JF, Lewis SB: Bottleneck factor and height-width ratio: Association with ruptured aneurysms in patients with multiple cerebral aneurysms. Neurosurgery 61: 716-723, 2007
9. Hong T, Wang Y: Unilateral approach to clip bilateral multiple intracranial aneurysms. Surg Neurol 72 Suppl 1: 23-28, 2009

10. Hopf NJ, Stadie A, Reisch R: Surgical management of bilateral middle cerebral artery aneurysms via a unilateral supraorbital key-hole craniotomy. Minim Invasive Neurosurg 52: 126-131, 2009

11. James Ling A, D'Urso PS, Madan A: Simultaneous microsurgical and endovascular management of multiple cerebral aneurysms in acute subarachnoid haemorrhage. Clin Neurosci 13: 784-788, 2006

12. Li M, Lin N, Wu J, Liang J, HeW: Multiple intracranial aneurysms associated with multiple dural arteriovenous fistulas and cerebral arteriovenous malformation. World Neurosurg 77: 398,2012

13. Martellotta N, Gigante N, Toscano S, Maddalena GF, Tripodi M, Settembrini G,Stroscio C, Distefano G, Citro E: Unilateral supraorbital keyhole approach in patients with middle cerebral artery (M1-M2 segment) symmetrical aneurysms. Minim Invasive Neurosurg 46: 228-230, 2003

14. Oshiro EM, Rini DA, Tamargo RJ: Contralateral approaches to bilateral cerebral aneurysms: A microsurgical anatomical study. J Neurosurg 87: 163-169, 1997

15. Rahmah NN, Horiuchi T, Kusano Y, Sasaki T, Hongo K: De novo aneurysm: Case reports and literature review. Neurosurgery 69: E761-767, 2011

16. Rahman M, Smietana J, Hauck E, Hoh B, Hopkins N, Siddiqui A, Levy El, Meng H, Mocco J: Size ratio correlates with intracranial aneurysm rupture status: A prospective study. Stroke 41: 916 920, 2010

17. Rajesh A, Praveen A, Purohit AK, et al: Unilateral craniotomy for bilateral cerebral aneurysms. J Clin Neurosci 17: 12941297,2010

18. Santana Pereira RS, Casulari LA: Surgical treatment of bilateral multiple intracranial aneurysms. Review of a personal experience in 69 cases. Neurosurg Sci 50: 1-8, 2006

19. Sun JJ, Zhao JZ, Wang S, Zhao YL, Wang ZY: Surgical treatment of multiple intracranial aneurysms. Beijing Da Xue Xue Bao 36: 272-275, 2004

20. Takeuchi S, Wada K, Otani N, Nawashiro H: Multiple intracranial aneurysms associated with hyper-IgE syndrome. Intern Med 51: 515-516, 2012

21. Thines L, Dehdashti AR, Howard P, Da Costa L, Wallace MC, Willinsky RA, Tymianski M, Lejeune JP, Agid R: Postoperative assessment of clipped aneurysms with 64-slice computerized tomography angiography. Neurosurgery 67: 844-854, 2010

22. Vega-Basulto SD, Silva-Adán S, Peñones-Montero R: Surgical treatment of multiple intracraneal aneurysms. Neurocirugia (Astur) 14: 385-391, 2003 